\title{
CERTAIN MEDICAL AND LEGAL PHASES OF EUGENIC STERILIZATION
}

\author{
By ABRAHAM MYERSON $†$
}

EVERY program which proposes a reformation of society, whether in its biologic or sociologic structure, awakens fierce controversy which is usually independent of the merits of the situation. This controversy becomes the greater whenever sex or reproduction becomes the foctus of the reform, since nowhere in the tangled web of human emotion and ideology is there more non-rationally based conduct than in this field. Therefore, it is to be expected that the points of view concerning etugenic sterilization disregard the essentials of proof and the camps of the proponents and opponents of sterilization find strange bed-fellows.

Despite indisputable verities, there are grave weaknesses in the postt1lates of those who favor eugenic sterilization. In the first place, there are large, relatively unexplored territories in psychiatry within which belong the major number of people who are to be sterilized. Secondly, genetics itself is an evolving science which as yet has little substantial fact and understanding to explain the mechanisms of the inheritance of mental diseases and mental aberrations. Thirdly, a reform of drastic nature must in a democracy have behind it a solid and educated public opinion, if it is to be enforced in any thoroughgoing way. Moreover, if this reform is to meet with judicial as well as public approval, it must be set within the framework of individual rights and immunities provided by the Constitution.

The limitations circumscribing the present day knowledge of psychiatry concerning those clinical groups in which sterilization is advocated must be recognized. The psychiatrist deals with diseases of different genesis and of varying degrees of substantial knowledge. These diseases are united only by the common fact of abnormal mentality, since the mental change under consideration may come from such diverse sources as the failure in sugar metabolism, syphilis, alcohol, endocrinal disorder, injury to the brain of whatever source, the changes of old age, and may even be entirely unknown as to etiology. ${ }^{1}$ The best known of the diseases with which psychiatry deals are fundamentally environmental in cause or so closely wrapped up with normal processes as to be mere accentuation of retrogression. It is highly significant that the diseases which are best known are non-hereditary in their genesis and that the diseases which are funda-

$\dagger$ Professor Emeritus of Neurology, Tufts College Medical School. M.D., Tufts College Medical School, 1908.

1. See Dayton, New Facts on Mental Disorders (1940). 
mentally unknown as to pathology and physiological mechanism are ascribed to heredity. "All cats look gray in the dark," and it is difficult to resist the temptation to postulate a unifying mechanism-hereditywhere little is known.

Thus general paresis, or, as it is officially known, dementia paralytica, is admittedly due to syphilis. There has also been. however, a valiant effort made to find a genetic basis for the susceptibility of any individual to brain disease following a syphilitic infection, since only five per cent of the total number of people infected by syphilis develop general paresis. But without syphilitic infection there is nothing to indicate that the individual who develops general paresis is fundamentally different from the mass of mankind, and from a practical standpoint it can be stated that whatever constitution is involved, syphilis is the essential factor in the multifactorial pattern by which the changes in the brain are brought about, and treatment remains the same regardless of any hypothetical genetic constitution. The situation is the same in that great bull: of mental diseases ascribable to arteriosclerotic brain changes and to the development of those plaques within the brain which bring about senile dementia. If any man lives long enough, he will develop an arteriosclerotic dementia or a senile dementia. Yet no one has been hardy enough to advocate sterilization to prevent the development of those mental diseases of the late fifties, sixties and seventies which are due fundamentally to the organic changes occurring with the passage of time. The situation is somewhat more complex when we turn to the alcoholic mental diseases. Chronic alcoholism, by which these mental diseases are brought about, may be constitutional. ${ }^{2}$ Certain facts indicate, however, that the chronic alcoholic belongs to no definite personality type; that the amount of chronic alcoholism varies with race and social culture, with the pressure of tradition and the general habits of a community. ${ }^{3}$ If there is inheritance as a basis of chronic alcoholism, it is too vaguely demonstrated to be of any scientific value.

2. See Mirerson, The Inherrtance of Miental Diseases (1925) 35-36; Bluhm, Darf die Erblichkeit der Alkoholschäden als bewicsen gelten? (1931) 18 Zrscrn. F. Sexualwissensch. 145-51; Diem, Dio psyehoneurotische erlihiche Belostmbg der Gcistestesgesunden und der Geisteskranken (1905) 2 Arcr. F. RAss. v. Gesseusch. Biul. \$9; Elderton and Pearson, A First Study of the Inftucuee of Parcutal Alcoholism on the Physique and Ability of the Offspring (1910) 10 Evgex. Lis. MEess; Mfoore, Alcoholism: Some Contemporary Opinions (1941) 224 NEw Exc. J. MIEn. 848-57; Peter, Germany's Sterilization Program (1934) 24 Ax. J. Pus. Henrta 187-91; Tillotson and Fleming, Personality and Sociologic Factors in the Prognosis and Treatment of Chronic Alcoholisn (1937) 217 New ENG. J. Mfen. 611-15.

3. See Exterson, Alcohol and Man (1932); Haggand and Jrllinew, Alconis ExploRed (1942) : Ayyerson, Alcoholism and Induction into Military Scrice (1942) 3 Q. J. Studies on Axc. 204-20, Alcohol: A Siudy of Social Ambialcnec (1940) 1 Q. J. Studies on Alc. 13-20 and The Social Psychology of Alcoholism (1940) 1 Dis. Nirnvous SYSTEM 1-8. 
Schizophrenia is a mental disease, however, for which eugenic sterilization has been advocated on the ground of hereditary causation. Unfortunately, there is no clinical definition of this condition which is universally accepted, and error in diagnosis, especially in differentiating it from manic-depressive psychosis, occurs very commonly ${ }^{4}$ - to the point where it can safely be said that individual idiosyncrasy on the part of the psychiatrist is a factor in diagnosis. No one knows its pathology despite heroic efforts and the development of many theories, although it is only fair to say that there is a moderate accumulation of facts concerning its physiology. ${ }^{5}$

The foregoing is also true of the manic-depressive states. The typical manic-depressive state presents a clear-cut syndrome, but there are many

4. See articles by Doering and Raymond, The Reliability of Observation in Psychiatric and Related Characterics and Elkind and Doering, The Application of Statistical Method to the Study of Mental Disease in Schizophrenia: Statistical Studies rrom the Boston Psychopathic Hospital, 1925-34 (1935) 249-57, 55-63. See further, Bancroft, Is There an Increase Amongst the Dementing Psychoses? (1941) 21 Trans. AM. Medrco-Psych. Ass'n 286; Elkind, Are Mental Diseases on the Increase? (1939) 13 Psychiar. Q. 165-72; Myerson, Errors and Problems in Psychialry (1940) 24 Ment. Hyg. 17-35, Are Mental Diseases on the Increase? (1939) 13 Psychist. Q. 177.

5. See Lewis, Research in Denrentia Praecox (1936); Angyal, Freeman and Hoskins, Pliysiologic Aspects of Schisophrenic Withdrazral (1940) 44 ARcr. Neunol. \& Psychiat. 621-26; Bowman and Raymond, Physical Findings in Schisophrctia (1929) 8 Am. J. Psychiat. 901-13; Brice, The Blood Fats in Schizophrenia (1935) 81 J. Nerv. \& Ment. Dis. 613-32; Carmichael, Rheingold and Linder, The Bromide Permeability Test in Schizophrenia (1935) 82 J. NERv. \& MENT. Dis. 125-33; Elvidge and Reed, Biopsy Studies of Cerebral Pathologic Changes in Schizophrenia and Manic-Depressive Psychosis (1938) 40 Arch. Neurol. \& Psychiat. 227-64; Finesinger, Cohen and Thomson, Velocity of Blood Flow in Schizophrenia (1938) 39 Arcr. Neurol. \& Psychiat. 24-36; Freeman, The Arm-to-Carotid Circulation Time in Normal and Schisophrenia Subjects (1934) \& Psychiat. Q. 290-99; Gamper and Kral, Experimentell-biologische Untersuchungen zum Schizophrenieproblem (1933) 146 ZTSChr. F. D. Ges. Neuroc. U. PsYchinT. 56798; Gellhorn, Experimental Investigations on the Influence of Hypoglycemia on the Cens tral Nervous System and Their Significance for the Treatment of Dementia Practor (1938) 12 Proc. Institute of Medicine of Chicago 5, The Action of Hypoglycemia on the Central Nerous System and the Problem of Schizoblyrenia from the Physiologic Point of View (1938) 110 J.A. M. A. 1433 and Effects of Hypoglycemia and Anoxia on the Central Nervons System (1938) 40 Arch. Neurol. \& Psychint. 125-46; Gjessing, Beiträge zur Kenntnis der Pathophysiologic des katatonen Stupors (1932) 96 ARcu. F. Psychiat. 319-473, (1935) 104 id. 355-416, (1938) 109 id. 525-95; Gottlieb and Linder, Body Temperatures of Persons with Schizophrenia and of Normal Subjects (1935) 33 Arch. Neurol. \& Psychiat. 775-85; Himwich, Bowman. Wortis and Fazekas, Biochemical Changes Occurring in the Cerebral Blood during the Insulin Treatment of Schizophrenia (1939) 89 J. Nerv. \& MENT. Dis. 273-93; Linton, Hamelink and Hoskins, Cardiozascular System in Schizophrenia Studied by the Schneider Mcthod (1934) 32 Arch. Neurot. \& Psychiar. 712-22; Looney and Freeman, Oxygen and Carbon Dioxide Contents of Arterial and Venous Blood of Schizophrenic Patients (1938) 39 Arch. Neurol. \& Psychist. 276-83; Sleeper and Jellinek, A Comparative Physiologic, Psychologic, and Psychiatric Study of Polyuric and Non-polyuric Schizophrenic Patients (1936) 83 J. NERv. \& MENT. Dis. 557-63. 
cases in which the diagnosis remains in doubt even after years of study and observation. Both the depressive and the manic phases often seem like accentuations of normal temperament, and it is quite certain that there is some degree of relationship to temperamental type, although the work of $\mathrm{K}_{\text {retschmer }}{ }^{6}$ ascribing a relationship to a pyknic body form can at this time be discarded as non-relevant. Little is known of its pathology or its physiology, ${ }^{7}$ and it seems definitely to occur without any specific environmental precipitation, ${ }^{8}$ just as does schizophrenia.

Here are two important groups of diseases which seem hereditary, yet the hereditary mechanism by which they are passed from one generation to another is unknown, and so is their essential psychopathology and organic physiological basis. For if they are hereditary, they must have an organic-physiologic basis, since we cannot scientifically conceive of mind passed from generation to generation without physical structure.

What has been here stated of schizophrenia and manic-depressive psychosis is also true of the groups of conditions lumped together as feeblemindedness. The various types of feeble-mindedness are united only by the fact that the individuals concerned are incapable of normal learning by reason of a postulated congenital defect in intelligence. ${ }^{9}$ The mental defectives vary in degree from the idiot, who is beneath the level of a reasonably intelligent two-year-old child, to the imbecile, who rarely if ever at all can learn to read and write, and to the moron, whose level of intelligence, although it permits him to carry on some work in the world, never evolves to a point where he is capable of handling abstract ideas. But this classification is not in terms of cause, since it only measures degrees of deficiency and has no relationship to causation. An individual suffering from the Mongolian type of feeblemindedness may have the same level

6. Kretscharer, Physigue and Charicter (1925).

7. See Peari, Constitution and Health (1933).

8. See Bumke, Discussion of Falthauser's faper, "Zur Frage der Stcrilisicrung geistig Abnorner" (1932) 96 Alig. Zтsch. F. Psychint. 372; Pollork, Mralzherg and Fuller, Hereditary and Encironmental Factors in the Causalion of Dementia Pracces and Manic-Depressize Psychoses (1934) S Psychlit. Q. 337-71.

9. See Brugger, Die Vererbung des Schwacusmans (1939); Davies, Sectar Control of the Feeblesinded (1923); Goddard, Feedlearmadedness, Its Cause and Consequences (1923); Pearson, On the Continuty of Mestral Defect (1914); Rosavoff, The Etiology of Mental Defictency with Special Refene:ice to ita OcCurrence in Twins (1937); Whldenskor, Investigations into the Causes of Mestal Deficiency (1934); Woodall, The Children of Meritally Defective asid Mentally Retarded Motmers (1932); Luxenburger, Endogenons Fecblcmindedncss and Sex Linked Heredity (1932) 140 ZTschr. F. D. Ges. NeunoL U. Psrenut. 320-32; Mott, Heredity in Relation to Mental Disease and Mental Deficiency (1026) 1 Brir. MED. J. 1023-26; Myerson, Nature of Feeble-19indedness (1033) 12 Ax. J. Psycuntr. 1205-23: Myerson and Elkind, Researches in Fechlemindedness (1930) 16 Bt'L. MI. Ls. Lers. MIExtal Drs. 108-229; Wells and Arthur, Effect of Foster-Home I'lacencut on the Intelligence Ratings of Children of Feebleminded Parents (1939) 23 ME:הr. Hyc. 277-\$5. 
of intelligence as a Cretin, but cause and pathology are very different in the two cases. Thus feeble-mindedness may arise from deficiency of the thyroid gland (cretinism) ${ }^{10}$ difficulty in the sugar metabolism (pyrtuvic acid metabolism), ${ }^{11}$ failure of the glands to develop as in Mongolian idiocy, ${ }^{12}$ other forms of pituitary disorder, ${ }^{13}$ birth injury, ${ }^{14}$ encephalitis occurring early in life, ${ }^{15}$ injury to the growing and developing brain by reason of whooping cough, ${ }^{16}$ and so through a long list of failures or injuries of body organs and brain. This is to say nothing of the accumulated defects which are known to arise through starvation, vitamin deficiency, extremely bad environmental conditions and the like. ${ }^{17}$

Many myths have been developed in the field of feeble-mindedness which have no scientific basis whatever. No animal breeder, however much he laid his emphasis on breeding and heredity, would think of subjecting the animals with which he was concerned to the cruel, stupid and harsh conditions which constitute the life situation of a great many people. Yet it is precisely in the field of feeble-minded, where such conditions are much in evidence, that the eugenists have laid most of their emphasis upon the need for sterilization. Elsewhere $I^{18}$ have criticized adversely, perhaps harshly, the work which has built up the "royal families" of the feeble-minded, the Nams, the Kallikaks, the Jukes, the Tribe of Ishmael, the Virginians, the Mongrels. Without in the least denying the important role of heredity, it can only be stated that low cultural level, especially occurring in sequestered groups, has been called feeble-mindedness on very scanty and insufficient evidence-evidence which any court of law would throw out as the worst sort of irrelevance and which science should not even consider.

The bulk of feeble-mindedness is utterly unknown as to genesis, pathology and disorder of physiology. I stress this because it is insufficient to say "heredity is a cause," since heredity is no unified set of mechanisms.

10. See Myerson and Elkind, loc. cit. supra note 9.

11. See Jervis, Genetics of Phenylpyrutic Oligophrenia: Contribution to Study of Influence of Heredity on Mental Defect (1939) 85 J. MENT. Scr. 719.

12. See Myerson and Elkind, loc. cit. supra note 9.

13. Ibid.

14. Ibid.

15. Ibid.

16. See Lurie and Levy, Personality Changes and Behavior Disorders of Childrc" Following Pertussis (1942) 120 J. A. M. A. 890-94.

17. See Freeman, Holzinger and Mitchell, The Influence of Environanent on the Intelligence, School Achievement, and Conduct of Foster Chitdren (1928); Paton and Findlay, Poverty, Nutrition and Growth (1926); Roberts, The Nutrition and Care of Children in a Mountain County of Kentucky (1922); Skeels, Updegraff, Welluian and Williams, A Study of Environmental Stimulation (1938); Skodak, The Mental Development of Adopted Children Whose Truc Mathers are Feeble-Minded (1938) 9 Chind Developa. 303-08.

18. Myerson, The Inheritance of Mental Diseases (1925) 77. 
If we say diabetes is inherited, we can at least define diabetes in terms of sugar metabolism. We can test the sugar metabolism of the ancestors and descendants, as well as of the siblings and collaterals. The diagnosis can be definitely and completely made. Even if we do not understand the complete genesis of diabetes on a physiological basis, we do know that disorder of the pancreas and very likely of the pituitary body, as well as the cortex of the adrenal, play important roles.

When we turn to vaguely understood diseases and ascribe them to heredity, we are at least in part explaining one unknown by another. The science of genetics has largely been built up by animal experimentation, and the work can at most be called brilliant and far-reaching. The establishment of Mendelian laws and the evolution of the theory of the gene represent two great landmarks in the history of the understanding of the mechanisms by which like begets like and by which variations appear. ${ }^{19}$ But this work is only in its beginnings; it is changing rapidly. There is a growing body of evidence to show that Mendelian laws explain only variations-what I have called "adjectival" attributes rather than the "nouns" of quality. ${ }^{20}$ Thus, Mendelian laws explain the greenness and the smoothness of pea pods, but they do not explain the universal occurrence of pods, which seems to be independent of Mendelian laws.

Much work has been done in the field of physiological genetics to show: that environment at all times plays a role in the evolution and evocation of hereditary qualities and that a drastic change of environment may call into play what seem like opposing or at least markedly different hereditary qualities. ${ }^{21}$ Experiments of far-reaching importance have shown that slowing up or accelerating the series of those timed evolutionary changes by which the fertilized egg becomes an individual of a species drastically alters the development of the individual. ${ }^{22}$ There may be, and I believe there is, sick germplasm ${ }^{23}$ which lasts over a considerable span of generations and adversely affects generation after generation. To separate environment from heredity is a useful dichotomy, but one which becomes per-

19. See, e.g., Goldschamid, Physiological Genetics (1938); Haldane, Hereditx and Politics (1938) 24-25; Jennings, The Brologrcal Basis of Hussi: Nitune (1930) 124; Morgan, The Theory of the Gene (1926); Goldschmidt, "Progressive: Heredity" and "Anticipation" (1938) 29 J. Hered. 140-42; Míuller, Arlificial Tronsmutation of the Gene (1927) 66 ScIENCE S4; Patterson, X-rays and Sonnatic Mrulations (1926) 17 J. HERED. $137-43$.

20. Myerson, The Relatiosship of Hercditary Factors to Mental Processes (1939)

19 Pub. Ass's Res. Nerv. Mient. Dis. 16-49.

21. See Jensings, The Biologtcal Basis of Husian Nature (1930) 124.

22. See Goldschumd, Physiological Genetics (1938); Ridnle, Tue Co:itrol of Heredity (1928) 62-71; Goldschmidt, "Progressive Heredity" and "Anticipalion" (1938) 29 J. HERED. 140-142.

23. See Forel, Abstinenz oder Maessigkeit (1910) and Eugenichl Stenulzatio: (1936) $75-78$. 
nicious when it becomes viewed as an absolute fact rather than as an abstraction of the human mind.

It is interesting to note that certain groups of people tend to become strict hereditarians and thus to view failure in life and the occurrence of disease as evidence of congenital inferiority. Conservative groups, as a rule, take this point of view. On the whole, these people are well satisfied with the status quo. They do not like the idea that their success and the failure of others may be accidental and environmental. The arrogant and the proud tend to be hereditarians and to neglect the environment entirely. Thus a leading feature of Nazi ideology is the importance of blood, and all the studies which emanate from Germany have emphasized racial superiority, stock superiority and eugenics. ${ }^{24}$ They have not hesitated to sterilize, and to destroy those whom they regard as inferior in race and of inferior germplasm and constitution. ${ }^{25}$ The biologists as a group, although with notable exceptions, ${ }^{26}$ have also tended to emphitsize the germplasm, largely because their experiments are carried out isolated as far as possible from the environment. They deal with animals of simple type and have mainly concerned themselves with the inheritance of simple qualities of bodily type rather than with the complex human attributes and that complexity of complexities-the human mind. Finally, those who have been impressed by the hopelessness of much of the therapeutics of psychiatry, who have been appalled by the rising cost of caring for the mentally sick, the epileptic, the feeble-minded and the criminals, have sought the impatient reform and have advocated sterilization more from despair than from real understanding.

If we turn to those who oppose eugenics, ${ }^{27}$ we find here, too, a curious conglomeration of bed-fellows. The Roman Catholic Church has laid down in the Encyclical of Pope Pius XI ${ }^{28}$ the basic proposition that sterilization is a mutilation which is not a punishment for crime and, consequently, an invasion of the sacred rights of man. Thus, a theologic concept is made the basis of opposition to what is essentially a biologic social reform. ${ }^{29}$ On the other hand, the Bolshevik ideology, which in so

24. See, for example, Lenz, Menschliche ERBLICHKEITSLEHRE UND RASSENHYYIENE (1932) ; Mayer, Gesetzliche Unfruchtbarmachung Geisteskranker (1927) ; Rudin, Studien ueber Vererbung und ENTStehung geistiger Stoerungen (1916).

25. Curiously enough, this ideology favors war which is by far the greatest cacogenic factor in the world, since the best are sent out to be destroyed.

26. As Jennings, The Biological Basis of Human Nature (1930) and Morgan, ThE THEORY OF THE GENE (1926).

27. See MAYer, loc. cit. supra note 24 .

28. Pius XI, Reconstructing the Social Order, Four Great Encyclicals 95-97.

29. This point of view may be linked up with the attitude of the Church towards birth control, namely, there must be no interference with procreation. It is curious that the Church, which insists on celibacy in its ministers and officers, is the most ardent advocate of unrestricted population increase. 
many respects is an anathema to the Catholic Church and which at least in its earlier development was completely opposed to religion, is also an enemy of eugenic sterilization and stresses environment. ${ }^{30}$ It is in general distasteful to Bolshevik science to attribute mental development and mental disease to heredity, and many enthusiastic Bolshevists have stated that by reforming society along the lines of Comnunism the mental diseases will and do diminish and disappear. And social reformers of the liberal type, those who are appalled by injustice and seek freedom for the individual, also tend to emphasize environment and to deny the importance of heredity as a factor in the genesis of the mental diseases, crime and social maladaptation. It is not an accident that students of history like Buckle, ${ }^{31}$ who ascribe the evolution of peoples to environmental forces, and social philosophers like Hobhouse, ${ }^{32}$ studying the evolution of morals, question, and quite cogently, the kind of proof on which eugenics rests.

The history of eugenic laws in the United States clearly demonstrates that unless there is a favorable public opinion, a new law which operates against the opinions of strong and established groups of people accomplishes little. About thirty states have passed eugenic laws of one type or another. ${ }^{33}$ For practical purposes these laws can be divided into two main groups: (1) Those mentally sick, feeble-minded, epileptic and criminalistic individuals likely to reproduce socially inadequate and maladjusted persons are to be sterlized by mandate and without any necessary consent on the part of themselves or those responsible for them; and (2) those laws which make such consent a necessary condition of sterilization. In most of the states, however, the number of sterilizations, compared to the number of those defined as liable to transmit adverse mental and social qualities to their descendants, is almost ridiculously small.

For example, in Connecticut a compulsory law was passed in 1909 and amended in 1919. Up to 1935, 391 operations had been performed (19 males and 372 females), an average of 15 sterilizations a year, which certainly does not indicate that the compulsion is utilized in any substantial degree. In Idaho, a non-compulsory law was passed in 1925, and up to January, 1935, 14 operations had been performed, indicating that the law is practically a dead letter. Michigan passed a compulsory law in 1923, which also provides for sterilization with consent. Until

30. This is in line with the general principle of economic determinism as fundamental in shaping the mind as well as the destinies of mankind.

31. Buckle, History of Civilization in England (1857-61).

32. Hobrouse, Morals in Evolution (1906).

33. For further data, see Cosmitree of the Aarericia Neurologrcar Ascocturio: for the Investigation of Eugenical Stermization, Eugenical Steriluzatro: (1936) c. II; Human Betteratent Foundation, Collected Papers on Eugenie Steriluatio:

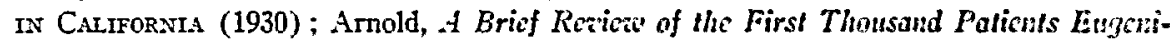
cally Sterilized at the State Colony for Epileptics and Fecble-Minded (1938) 43 Proc. Axr. Ass'n Mient. Def. 56-63. 
January, 1935, 1,239 operations had been performed ( 307 males and 932 females), an average of slightly over 100 a year in a populous state. A law was passed in Nebraska in 1929, which is compulsory for feebleminded before leaving institutions and non-compulsory for the insane before discharge or parole from a state hospital. Up to January, 1935, 276 sterilizations (112 males and 164 females), or about 46 a year had been performed. In 1931, a compulsory law was passed in Oklahoma, and by January, 1935, 8 operations had been performed. And in Washington, a voluntary law was passed in 1921, but in 14 years only 30 operations had been performed. If sterilization laws of any type are to be passed, even though the scientific proof is incontestible, it is clear that public education is essential as a preliminary to adequate enforcement.

Certain myths must be dispelled in order to view the problem realistically. One argument made for widespread sterilization is that the number of insane is increasing by leaps and bounds and, therefore, the race is threatened in a serious way by the propagation of the unfit. ${ }^{34}$ It is true that the admission rate to hospitals for mental disease has gone up enormously within the past few generations. ${ }^{35}$ But a growing public conscionsness that mental disease is treatable has been almost solely responsible for this increase. If we take two American states, Massachusetts and New York, ${ }^{36}$ as representative of communities with well-established hospitals and with a reasonably good understanding of mental disease, we find that in these two states the commitment rate has changed but little during the past twenty years. Moreover, this is true of England, Wales and New Zealand. ${ }^{37}$

34. See, for example, Darwin, The Descent of Man and Selection in Relation to Sex (1882) 133-34; Hunian Betternent Foundation, loc. cit. silpra note 33; Laughlin, Eugenical Sterilization (1926) and The Legal Status of Eugenical Sterilization (1929); Malthus, An Essay on the Principle of Population (1803); 1 Spencer, The Principles of ExHics (1892) 548; Farrar, Social Aspects of Mcutal Dcficiency (1926) 16 CAN. M. A. J. 1233-38; Herd, Sterilization of the Mentally Defective (1933) 2 LANCET 783-86; Landman, The Human Sterilization Movement (1933) 24 J. Crms. Law \& Criminology 400-08; Watkins, Selective Sterilization (1932) 16 Bull. Mass. Dep't Ment. Dis. 59-68.

35. See Dayton, New Facts on Mental Disorders (1940); Landis, Carney and Page, Magnitude of the Problem of Mental Disease (1939) 149-55, Mental PAtients in State Hospitals 1926 and 1927 (1930) and Patients in Hospitals yor Mental Disease, 1935 (1937) ; Dorn, Incidence and Future Expectancy of Mchlal Disease (1938) 53 Pub. HeAlth Rep. 1991; Elkind, Are Mental Diseases on the Increase? (1939) 13 Psychiat. Q. 165-72; Pollock and Malzberg, Trends in Mculal Discasc (1937) 21 Ment. Hyg. 456; Wile, The Threat of Mental Disease (1940) 92 J. Nerv. \& MENT. Dis. 323-42; Winston, The Assumed Increase of Mental Disease (1935) 40 Axr. J. Sociol. 427-39.

36. See, Committee of the American Neurological Assoctation for the Investigation of Eugentcal Sterilization, Eugenical Sterilization (1936) 27 ef seq.

37. See Winston, loc. cit. suspra note 35 . 
There are cogent reasons why mental disease would not be expected to increase in the more enlightened communities of the United States and Europe. In the first place, the marriage rate tends to be low in most of the important and transmissible mental diseases. ${ }^{33}$ This is easily understandable since marriage acts as a barrier to the unsuccessful, the unattractive, the odd and the peculiar, and those who create unfavorable reactions. Moreover, in many of the mentally sick, there is a lessened sexual drive. The divorce rate ${ }^{39}$ is higher, too, as life with a person of unstable temperament and on the road to a mental disease is very difficult and often unbearable. The death rate is also greater, ${ }^{30}$ for the conditions of life tend to be worse for the mentally sick than for the mentally well, the general health suffers with most mental diseases, and there is a general biologic defect. And finally, the birth rate of the mentally sick is lov;, contrary to the usual opinion. ${ }^{41}$ This is in part a resultant of the lower marriage rate and the greater death rate, but is to some extent independent of it.

In the case of the feeble-minded the above holds true, even though it runs quite completely counter to the unscientific studies represented by the Nams, the Kallikaks or the Jukes. The British Report of the Departmental Committee on Sterilization ${ }^{42}$ flatly declares that the prolificity of the feeble-minded is a myth, and a paper by Walter E. Fernald ${ }^{43}$ shows

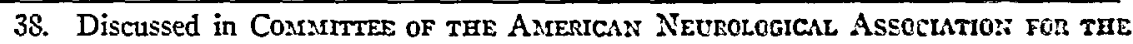
Investigation of Eugenical Sterilization, Eugenical Sterilizatio: (1936); Aryeison, The Inheritance of Mextal Diseases (1925) 109 at seq.; Pollock aid Futibuse, Cosiparattve Statistics of State Hospitals for Mlemtal Diseases (1922); Dayton, Marriage and Mental Disease (1936) 215 NEw ExG. J. MFeo. 153-55; MFalzberg, Marriage Rates Anong Patients with Mental Disease (193S) 22 Mentr. Hrc. 634. Püpenoe, Eugenic Sterilization (1928) 1 J. Socint Hyc. 27.

39. See Popenoe, Social and Economic Status of the Sterilizad Feclicninded (1923) 12 J. Applied Psychol. 304-16.

40. For extended discussion, see Dayton, Mortality in Miextal Deficie:scy OVer a Fourteen Year Pertod (1931); Comarttree of the Asrericas Neurolggical Assuctation for the Intestigation of Eugenical Steri.ization, Evgenicil Sterinizatio: (1936) 75-78, Mental Patients in State Hospitals (1931) and Mortality of Patients in Hospitals for Mental Diseases (1928) : Rudra. Studes vener Verendung und Entstemung geistiger Stoerungen (1916) 45; Dayton, Doering, Hilferty, Mlaher and Dolan, Mortality and Expectation of Life in Mestal Deficiency in Massuchusefts (1932) 206 NEW Eng. J. Mird. 555-70, 616-31.

41. See Dayton, New facts on Miental Disoruers (1940); Pollocts atid Futeush, Coarparative Statistics of State Hospitals for Miental. Diseises (1922); Report of the Departarentall Cominttee on Sterilization (1934); Myyerson and Elkind, Research in Feeble-1Yindedness (1930) 14 Buls. Masss. Dept. MIE:Tat. Dis. 10\$229; Essen-Möller, Ucber die Fortpflaninung zon Geisleshranken (1936) 30 Arcu. F. Rassen-u. Geseulschaftsbiol. 432-36; Popenoe, Fecsmdity of the Insanc (1928) $19 \mathrm{~J}$. HERED. SO.

42. Report of the Departasental Coaramttee on Stermizamon (1934).

43. Fernald, After-Care Study of the Patients Discharged fross Wavencey for a Period of Twenty-Five Years, Ungraded (1919). See also Mirerson, op. cil. supra note 2, at 81 . 
that in the case of the discharged and known feeble-minded from an institution in Massachusetts, there was a low marriage rate and a very low birth rate. What is mistaken for the high birth rate of the feeble-mincled is the high birth rate of low cultural level. Statistics collected by Ellind and the author, ${ }^{44}$ as well as by Popenoe, ${ }^{45}$ indicate that the feeble-minded tend to come from families representative of the community as a whole, and that there is not an unbalanced or disproportionate birth rate. Dayton's statistics ${ }^{46}$ indicate very clearly that the death rate amongst the feeble-minded is proportional to the degree of feeble-minded and is greater than that of the normal population.

It seems safe to say that these statistics disclose the factors which operate against any considerable increase of the mental diseases and of feeble-mindedness. It is also true that we have become much more conscious of these conditions. A defective individual might adjust to a sim* ple pastoral life but not be competent to meet the stresses of a civilization which demands the ability to carry on relatively complex mental processes. A feeble-minded shepherd would not be particularly noticed, but a moron trying to operate machinery would show his defectiveness very quickly.

These problems have been considered in a report of the committee of the American Neurological Association for the Investigation of Eugenical Sterilization, ${ }^{47}$ of which committee the author was chairman. Based on a review of the world's literature, and with especial consideration of the fine studies of those touchstones of modern genetics, the monozygotic (or identical) twins, ${ }^{48}$ this committee reached the following conclusions:

44. Myerson and Elkind, Researches in Fecblemindedness (1930) 16 Bul.. MAss. Dept. Mental Diseases 108-229.

45. Popenoe, Eugenic Sterilization (1928) $1 \mathrm{~J}$. Social Hyg. 27, Fecundity of the Insane (1928) 19 J. HERED. 80 and Social and Economic Stahts of the Sterilized Fecbleminted (1928) 12 J. Applied Psychol. 304-16.

46. Dayton, New Facts on Mental Disorders (1940), Eugenical Sterilization (1936) 75-78 and Mortality in Mental Deficiency Over a Fourteen Year Period (1931); Dayton, Doering, Hilferty, Maher and Dolan, loc. cit. supra note 40; Dayton, Influence of Size of Family upon the Characteristics of the Mentally Deficient (1935) 91 A.r. J. Psychiat. 799-832.

47. Committee of the American Neurological Association for tile Investiontion of Eugenical Sterilization, Eugenical Sterilization (1936).

48. Significant here are Newman, Freeman and Holzinger, Twins: A Study of Heredity and Environment (1937); SChwesinger, Heredity and Environment (1933) ; von Verschuer, Twin Research from the Time of Francis Galton to the Present Day (1939) 62-81; Woodworth, Heredity and Environment (1941); Carter, Ten Years of Research on Treins (1940) 39 Yeardk. Nat. Soc. Stud. Educ. 235-55; Myerson and Elkind, Researches in Feeblemindedness (1930) 16 BuLL. Mass. DERT. Mental Dis. 108-229; Rosanoff, Handy, Plesset and Brush, The Etiology of So-Called Schizophrenic Psychoses, with Special Reference to their Occurrence in Truins (1934) 91 Am. J. Psychiat. 247-86; Rosanoff, Handy and Plesset, The Etiology of Manic-Dc- 
First, schizophrenia ${ }^{49}$ and manic-depressive psychosis ${ }^{50}$ have an inherited basis although this is not the entire story, for there is very likely an environmental root or factor of some kind which at present is entirely unknown.

Second, the bulk of feeble-mindedness rests on an hereditary basis of some type. There is an inheritance to intelligence although not of the "like begets like" variety, since despite the fact that there are families of feeble-minded, the bulk of the feeble-minded comes from families which are representative of the total community in social standing, achievement and general intelligence. This is certainly true of the cases one sees in private practice where sporadic feeble-mindedness frequently appears among groups of the highly intelligent and where relative feeble-mindedness-in the sense that an individual develops above the level of the accepted standard for the feeble-minded but is deficient in intelligence compared to the group with whom he has lived-represents by far the greatest part of feeble-mindedness. Nevertheless, no serious worker in the field of

pressize Syndromes with Special Reference to their Oecurrence in Tavins (1935) 91 Ass. J. Psychiat. 725-61; Rosanoff, Handy and Rosanoff, Etiology of Epilcpsy asith Special Reference to its Occurrence in Tains (1934) 31 Arch. Neurol \& Psychiat. 1165.

49. Compare Hofrasann, Die Nach konagenschaft get endogenen: Psychose:: (1922) and Vererbung und Seelenleben (1922); Hogrex. The Axalysis of Pedigrees 1:: "The Chatces of Morbin Inheritance" (1934) 405: Kallmaxw, Genetics of SchizoPHRENIA (1938) ; Galachyan, Similarity of Psychoses in Schizophrenic Brothers and Sisters in Relation to Heredity of Schizophrenia (1933) 2 Sover. Neunopar. Psrkur I. PsirnoGIG. 91-103; Hoffmann, Incidence of Hercditary Psyehoses, Sehizophrenia and Efilessy in Children of Schizophrcnics and Epileptics (1928) 114 ZTscer F. D. Ges. Neurom v. Psychiat. 630-46; Hogben, The Intcraction of Heredity and Entromant (1933) $79 \mathrm{~J}$. Mentr. SCI. 590-601; Juda, Incidence of Dementia Praciox in Grandehildren of Selizaphrenics (1928) 114 ZTSChr. F. D. Ges. NeuRoz. U. Psychi.s. 630-46; Kallmann, Heredity, Reproduction and Engenic Procedure in the Ficld of Selhizophrenia (1938) 23 Ever:?. News 105-13; Koller, Heredity in Schizophrenia (1939) 104 ZTscur. F.D.Ges. Neutom Psychiat. 199-288; Lange, Role of Heredity in Pathogenesis of Schizophrouia (1929) 42 WIEN. KLIN. WCHASCHR. 1213.

50. Compare Essen-Möller, Manic-Depressive-Fertiltiy of Certar: Groups op Mextally Diseased (1935); Kraepelin, Manic-Depressine Irsanity a:id Paraiou (1921); Pollock, Malzberg and Fuller, Heredstary and Encironmental Foctors is the Causation of Denentia Praccox and Manic-Depressioe Psychuses (1934) S Psychur. Q. 337-71; Berze, Theory and Hereditary Aspect of Manic-Depressize Insanily (1930) 32 Psychiat. Neurol. WCHnschr. 473-77; Bleuler, Manic-Depressize-Heridity and Hereditary Prognosis in Cross Section of Popnlation (1937) 9 Fontschn. D. Neurow. Psychiat. 250-64; Braun, Manic-Depressize-Rezicio of Lilcralure (1937) 9 Forrscun D. Neurol Psychiat. 380-90; Kretschmer, Familial Forms of Psychoses (1933) 80 MUENCHNER MED. WCHNSCHR. 10S4; Luxenburger, Erbpropmose und pralsisthe Ettuzenil: im cyclothymen Kreise (1932) 5 NervenazzT 505-18; Pashin, Hereditary Factors is Manic-Depressive Psychoses (1930) 24 Arch. Neurol. \& Psycrur. 745-52; Slater, Hcreditary Factors in Manic-Depressize Psychosis (1938) 163 ZTscar. F. D. Ges. NeunoL v. Psychiat. 1. 
feeble-mindedness doubts that a great deal of mental deficiency, if not the most of it, is congenital and probably hereditary in origin."

Third, there is some constitutional etiologic basis for epilepsy, ${ }^{52}$ but it is not proven to be of hereditary origin. ${ }^{53}$ Recent work has tended to show that there may be more of an hereditary basis than was assumed to be the case, particularly the study of the brain waves by a notable Boston group of workers-Lennox, Gibbs and Gibbs. ${ }^{\text {bi }}$ I do not believe, however, that the study of brain waves has reached the precision and reliability which these workers assume it has. Nor do I agree that the kind of brain wave they describe is limited to epilepsy, so that their studies showing abnormal brain waves in the parents, collaterals and siblings of epileptics as proof of the hereditary basis of epilepsy are perhaps not as well founded as might be believed the case at first glance. ${ }^{55}$ Epilepsy, or, more precisely, the convulsive states, appears to be producible in all forms of life beyond the most primitive, can be brought about in any human being

51. See, e.g., Dayton, New Facts on Mental Disorders (1940); Goddard, Feedlemindedness, Its Cause and Consequences (1923); Herd. Inheritance of Mental Deficiency in "The Chances of Morbid Inheritance" (1934) c. 5 ; Penrson, On tile Continuity of Mental Defect (1914); Tredgold, Mental. Deficiency (1929); Wildenskov, Investigations into the Causes of Mental Deficiency (1934); Myerson, Nature of Feeble-Mindedness (1933) 12 Am. J. Psychiat. 1205-26; Myerson and Elkind, Researches in Feeblemindedness (1930) 16 Bun.. Mass. Dept. Mental Dis. 108-229; Baker, Mental and Social Status of 1500 Patients in Obstetrical Clinic of Johns Hopkins Hospital (1933) 52 Bull. Johns Hopkins Hospital 275-314; Doll, II Intal Devclopment and Heredity (1940) 4 J. Consult. Psychol. 243-44; English, The Fecble-Minded Problem (1931) 11 Am. J. Psychiat. 1-8, Feeblemindedness Today, A Revicz of Some Recent Publications on the Subject (1930) 21 J. HeRED. 421-30; Herd, Stcrilization of the Mentally Defective (1933) 2 LANCET 783-86; MeNeil, Heredity a Minor Factor in Mculal Deficiency (1934) 1 BrIT. M. J. 584-85; Penrose, Some Genetical Problems in Mental Deficiency (1938) 84 J. Ment. Scr. 693-707; Shuttleworth, Rosanoff, Handy and Plesset, On the Etiology of Mental Deficiency (1938) 29 J. Evuc. Psychol. 374-83.

52. Committee of the American Neurological Association for the Investigation of Eugenical Sterilization, Eugenical Sterilization (1936) 136-44.

53. See Echeverria, ON EpIlepsy (1870); Brain. The Inheritance of Epilcpsy (1925) 29 Q. J. Med. 229-310; Burr; Heredity in Epilepsy (1922) 7 ARcri. Neurou. \& Psychiat. 721-28; Cobb, Canses of Epilepsy (1932) 27 Arch. Neurol. \& Psycuiat. 5; Stein, Hereditary Factors in Epilepsy (1933) 12 Aur. J. Psycmunt. 989-1027; Thom, Epilepsy in the Offspring of Epileptics (1916) 175 Bost. MEd. \& SuRG. J. 573-75, 599-600.

54. Gibbs and Gibbs, Atlas of Electro-encephalographic Records (1940); Gibbs, Davis and Lennox, The Electro-Encephalogram in Epilepsy and in Conditions of Impaired Consciousness (1935) 34 АRCH. NeURoz. \& Psychiat. 1133; Gibbs, Gibbs and Lennox, The Electro-Encephalogram in Diagnosis and in Localization of Epileptic Scizures (1936) 36 Arch. Neurol. \& Psychiat. 1225; Lennox, Gibbs and Gibbs, The Inheritance of Epilepsy as Revealed by the Electro-Encephalograph (1939) 113 J. A. M. A. 1002, (1940) 44 Arch. Neurol. \& Psychiat. 1155.

55. An important paper attacking their assumptions in this matter is that of Finlcy and Dynes. Finley, Knox and Dynes, Electro-Encephalographic Studies in EplLEPSY (1942). 
by drugs, electricity, and brain damage, and thus differs radically frum schizophrenia and manic-depressive psychosis. The most that as yet can . be said as to its relationship to heredity is that some individuals and familial groups are more liable to it.

Fourth, crime, one of the conditions which ardent eugenists expect to be reduced by sterilization ${ }^{56}$ is generally non-hereditary in nature. ${ }^{5 \pi}$ There are too many social variables in crime for it to be accepted as an essentially biologic condition. It may well be that some criminals are abnormal variants, but this is surely not true of all of them. The studies which have purported to prove that crime is hereditary have, on the whole, been too precariously based on the shape of ear lobes, height, weight or head-form to have reached a place worthy of the name scientific at this time. There are individuals who lack social feeling, who are crass and crude egotists, who find conformity difficult, but such individuals arc found at the top of the social ladder and among the successful as well as at its bottom and among those who repose in jails.

The committee, taking into account the social structure of our times, the prejudices and taboos which reign, and the welter of opinion, concluded that certain of the mental diseases rest on a constitutional and an hereditary basis, and that a program of eugenic sterilization is indicated and desirable. These diseases, excluding from consideration at this point the very rare neurologic disorders, ${ }^{58}$ are schizophrenia, manic-depressive psychosis, most of the forms of feeble-mindedness, and possibly epilepsy. We advocate, therefore, the passage of voluntary laws to apply to certified cases of these diseases within private or public hospitals or cared for in the community.

The most important conclusion is that neither the psychiatrist nor the eugenist can afford to be dogmatic in his opinion. What is needed most of all is an organized research, preferably by some governmental agency such as the United States Public Health Service. This research could coordinate long-time studies on the epidemiology, psychology, physiology,

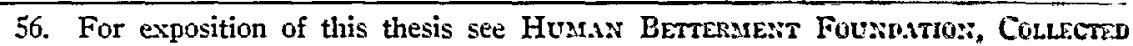
Papers on Eugenic Sternization in Califordia (1930): Milyes, Gesetzliche U:fruchtbararachudg Getsteskranter (1927): Ploscone, Ciuses uf Crame (1930): Conmuttee of the Aasericax Neurological Assochtion for tue Investigation of Eugenical Sterilization, Eugenical Sterilization (1936) 75-78; Creutz, Der Einfluss der erblichen Belastung and dor Unainlt bei Criminellen (1931) 95 ALLc. ZTscrn. F. Psychiat. 73-106; East, Heredity and Crime (1928) 20 Evc. Rer. 169-72; Popenoe, Twins and Criminals (1936) 27 J. HerEd. 38S-90; Riedl, Stcrilization of Young and Old Criminals and Descendants of Criminals in Light of New German Lan of July 14, 1933 (1933) 93 ArсH. F. Krisrivol. 125, 238; Stumpfl, Kriminalitüt und rererbung (1939) 5 Hande. Erbitol. 1223-74.

57. Comimitee of the Axrerican Neubological Assochation for the Investigatio: of Eugenical Sterilization, Eugenical Sterilization (1936) $150-52$

58. Id. at $145-49$. 
chemistry and physics of the patients who form the subject matter of psychiatry. Groups of specially trained men could be set free from economic pressure to devote their lives to such researches. Moreover, an institute organized for a continuing program of at least one hundred years should be established for the study of human heredity. One man's lifetime is not long enough, because he lives only as long as his subjects, and his working career is rarely more than forty years. Several generations of people must be intimately known and their lives scientifically recorded before we can know much of human heredity. The workers in this institute should include not only scientists in each field which is pertinently involved, but also the best of statisticians and high-grade field workers capable of social investigation of an objective type.

It must be emphasized that one of the cardinal assumptions of the rabid eugenists, ${ }^{59}$ namely, that there is a fundamental antagonism between eugenics, or being well-born, and euthenics, or social betterment, is not in its generality true. There are social ameliorations and euthenic measures which probably are not of value to the race and are even harmful. Thus, nursing along a defectively constituted child so that he reaches maturity, can marry and procreate, certainly seems non-eugenic, even cacogenic. Furthermore, whatever steps are taken for the cure of schizophrenia, for example, should be associated with eugenic measures, and if methods are finally discovered for its cure, it may be of great importance to establish sterilization as a condition of treatment. In its broader scope, however, euthenics makes the race better rather than worse. Epidemics, malnutrition, and the serious adverse conditions under which many of the people of the world live very definitely injure otherwise sound persons, and prevent the full development of hereditary potentiality. Accident, disease, social privation and cacoethenic influences are also cacogenic measures in that they injure germplasm. There is no reason to believe that the germplasm, as well as the rest of the egg and the seed, may not be injured by the same illness that affects the heart, the lungs, or the brain of the individual. The program of euthenics may, therefore, be considered a part of eugenic betterment; and legislation which provides the best of food and housing, sunshine, reasonable hours of employment and adequate compensation, social insurance of necessary kinds, and good medical care, although it may be defined as euthenic, is also eugenics of a positive type.

It is time medical biology and law made some kind of a formal alliance, with a division of labor and a unified purpose for the social good. Science, as one of the partners, should gather the information by scientific tech-

59. As seen in Darwin, The Descent of Man and Selection in Relation to Sex (1882) 133-34; Haeckel, Freie Wissenschaft Und freie Lefire (1908) 68-69; HuXleY, Evolution and Ethics (1894); Tille, Von Darwin bis Nietzsche (1895) 120; MaLthus, An Essay on the Principle of Population (1803). 
niques, analyze its experiences and experiments according to statistical methods, and so reach proven conclusions. The job of putting the indicated program of social reformation into activity belongs to the law. Having assured itself that the propositions evolved by science are solidly established and accepted, it faces the task of manipulating a prejudiced society into line. Whatever laws are passed must be capable of being enforced, for however good scientific theory and postulates may be, there are social principles of conduct, taboos, unreasonable attitudes and nonrational traditions which must be taken into account. Moreover, the constitutional rights of the individual must be protected, ${ }^{60}$ even though to do so seems to retard reform. The law or, more personally, the legislators, the executive and legal directors of society have the duty to be equitable and practical at one and the same time in such a matter as eugenic sterilization.

60. For a discussion of the constitutional problems raised by sterilization legislation, see Cook, Engenics or Enthenics (1943) 37 ILL. L. REv. 287; Note (1942) 51 YALE L. J. 1350. 